\title{
Perlakuan Benih diantara Periode Penyimpanan untuk Meningkatkan Daya Simpan Benih Kedelai
} (Glycine max (L.) Merr.)

Middle Storage Treatment to Extend Soybean (Glycine $\underline{\max }$ (L.) Merr.) Seed Longevity

\author{
Shinta Nugraheni Kusumastuti, Maryati Sari ${ }^{*}$ dan Eny Widajati
}

Departemen Agronomi dan Hortikultura, Fakultas Pertanian, Institut Pertanian Bogor (Bogor Agricultural University), J1. Meranti, Kampus IPB Darmaga, Bogor 16680, Indonesia Telp.\&Faks.62-251-8629353 e-mail agronipb@indo.net.id

*Penulis untuk korespondensi: maryatisari@yahoo.com

Disetujui 17 Mei 2017/Published online 22 Mei 2017

\begin{abstract}
The objective of this research was to get middle storage treatment to extend soybean seeds longevity. The research was conducted at Seed Technology Laboratory, Department of Agronomy and Horticulture, Faculty of Agriculture, Bogor Agricultural University in December 2013 to April 2014. Treatments were applied, i.e (1) washing with warm water, (2) washing with cold water, (3) washing with mancozeb fungicide, (4) drying in the sun. Seeds that had been treated (1), (2) and (3) dried until the moisture content reaches 8-9\% by drying in the sun. Seeds were stored in a low temperature $\left( \pm 5^{\circ} \mathrm{C}\right)$ and in ambient temperature $\left(26-30{ }^{\circ} \mathrm{C}\right)$ packed in polypropylene plastic $(0,08 \mathrm{~mm})$. The results showed that the untreated seed be able to retain $80 \%$ germination percentage just for 6 weeks. Seed treatment washing with mancozeb fungicide, washing with cold water and drying the seeds without washing first could increase seed viability and germination percentage could be maintained $>80 \%$ until 16 weeks after treatment either at low temperature storage or ambient storage. Drying seed in the sun could be the best choice as seed enhancement for middle storage treatment because it was cheap and easy to do and give good results.
\end{abstract}

Key words : invigorasi, viability, vigor

\section{ABSTRAK}

Tujuan penelitian ini adalah mendapatkan perlakuan benih diantara periode penyimpanan untuk meningkatkan daya simpan benih kedelai. Penelitian dilaksanakan di Laboratorium Teknologi Benih, Departemen Agronomi dan Hortikultura, Fakutas Pertanian, Institut Pertanian Bogor pada bulan Desember 2013 hingga April 2014. Perlakuan benih yaitu (1) pencucian dengan air hangat, (2) pencucian dengan air dingin, (3) pencucian dengan fungisida mankozeb, (4) penjemuran di bawah matahari. Benih yang telah diberi perlakuan (1), (2) dan (3) dikeringkan hingga mencapai kadar air 8 - 9\% dengan cara dijemur di bawah matahari. Benih disimpan di ruang suhu rendah $\left( \pm 5{ }^{\circ} \mathrm{C}\right)$ dan di ruang kamar $\left(26-30^{\circ} \mathrm{C}\right)$ menggunakan plastik polipropilen $(0.08 \mathrm{~mm})$. Hasil penelitian menunjukkan bahwa benih yang tidak diberi perlakuan hanya mampu mempertahankan daya berkecambah 80\% hingga 6 minggu. Perlakuan pencucian benih dengan fungisida mankozeb, pencucian dengan air dingin dan penjemuran benih tanpa dicuci terlebih dahulu dapat meningkatkan viabilitas benih serta dapat mempertahankan daya berkecambah $>80 \%$ hingga akhir penyimpanan, 16 minggu setelah perlakuan baik pada penyimpanan suhu rendah maupun suhu kamar. Perlakuan penjemuran di bawah sinar matahari dapat menjadi pilihan terbaik sebagai perlakuan invigorasi benih diantara periode penyimpanan karena murah dan mudah dilakukan serta memberikan hasil yang baik.

Kata Kunci : invigorasi, viabilitas, vigor 


\section{PENDAHULUAN}

Kedelai merupakan salah satu komoditi pangan utama setelah padi dan jagung. Kedelai termasuk dalam kacang-kacangan yang memiliki tingkatan nutrisi sangat tinggi terutama protein nabati. Tahu dan tempe merupakan hasil olahan kedelai yang dikonsumsi oleh masyarakat sebagai lauk pauk atau cemilan. Selain karena kandungan gizinya yang tinggi, harga olahan kedelai dapat dikatakan murah, sehingga olahan kedelai sangat cocok untuk masyarakat Indonesia. Produksi kedelai dalam negeri hanya mencukupi sekitar $40 \%$ dari kebutuhan nasional yang sebesar 2 juta ton/tahun, sehingga kekurangannya harus dipenuhi melalui impor (Puslitbangtan 2013).

Berdasarkan kenyataan di lapangan diketahui bahwa benih kedelai yang dijual oleh toko-toko penyalur benih adalah benih-benih yang telah melewati masa simpan lebih dari 3 bulan dan disimpan pada kondisi suhu kamar sehingga menyebabkan mutu benih menurun. Kondisi tersebut menyebabkan ketika benih ditanam di lapangan oleh petani, benih tidak menunjukkan perkecambahan yang baik (Ruliyansyah 2011). Rendahnya mutu perkecambahan benih disebabkan oleh turunnya vigor dan viabilitas benih kedelai selama penyimpanan. Peningkatkan daya simpan benih dapat diupayakan melalui perlakuan pada benih baik diawal penyimpanan maupun diantara periode simpan. Benih kedelai biasa disimpan dalam ruang simpan terbuka.

Penjemuran atau pencucian benih dengan air hangat maupun air dingin diharapkan dapat menekan perkembangan mikroorganisme, disamping adanya efek positif lain yang mungkin diperoleh sehingga viabilitas benih setelah disimpan tetap tinggi. Perlakuan tersebut merupakan bagian dari invigorasi karena invigorasi sendiri adalah perlakuan yang diberikan untuk meningkatkan vigor benih yang ditunjukkan oleh perbaikan performansi benih baik secara fisiologis maupun biokemis, dengan berbagai perlakuan benih pasca panen atau pra tanam (Ilyas 2001).

Beberapa perlakuan invigorasi benih juga digunakan untuk menyeragamkan pertumbuhan kecambah dan meningkatkan laju pertumbuhan kecambah. Invigorasi benih dapat dilakukan dengan cara perendaman benih dalam air (Rudrapal dan Nakamura dalam Ruliansyah 2011), priming dengan berbagai macam larutan (Heydecker dalam Ruliansyah 2011), dan penggunaan matriconditioning (Khan et al. dalam Ruliansyah 2011). Teknik ini banyak memberikan manfaat pada berbagai komoditas, namun sangat riskan untuk benih kedelai jika benih akan disimpan kembali. Hasil penelitian Utami (2013) menunjukkan benih yang diberi perlakuan priming perendaman dalam air, $\mathrm{CaCl}_{2}$, $\mathrm{KNO}_{3}$, dan asam askorbat disimpan pada kadar air $12-13 \%$ karena pengeringan lebih lanjut mengakibatkan retak-retak pada permukaan benih. Retak-retak pada permukaan kulit benih menjadikan penampilan benih kurang menarik dan menurunkan mutu fisik dari benih itu sendiri. Hal ini menjadi kelemahan dari teknik hydropriming dan priming/Osmoconditioning untuk penyimpanan.

Penelitian Erinnovita et al. (2008) pada benih kacang panjang menunjukkan bahwa perbedaan perlakuan metode invigorasi berpengaruh terhadap kadar air akhir yang dicapai setelah perlakuan. Invigorasi dengan perendaman air (soaking) selama 15 jam meningkatkan kadar air dari $\pm 8 \%$ menjadi $31-34 \%$, perlakuan matriconditioning dengan mengunakan media serbuk gergaji pada tekanan -1.25 MPa selama 20 jam meningkatkan kadar air menjadi $14-17 \%$, sedangkan benih dengan perlakuan priming dengan media pasir pada tekanan $-1.25 \mathrm{MPa}$ selama 20 jam memiliki kadar air benih 8-10\%.

Perlakuan invigorasi yang telah banyak memberikan manfaat bagi petani, masih perlu lebih banyak diteliti, khususnya invigorasi diantara periode penyimpanan (middle storage treatment). Pada perlakuan invigorasi sebagai middle storage treatment manfaat invigorasi diharapkan dapat tetap dipertahankan selama periode tertentu dalam penyimpanan atau selama periode distribusi hingga sampai ke tangan petani.

Perubahan kadar air (KA) pada proses invigorasi dan saat benih dikeringkan kembali untuk disimpan diduga akan berpengaruh pula terhadap daya simpannya. Pemilihan metode invigorasi yang tepat perlu dilakukan tidak hanya untuk memperbaiki perkecambahan tetapi juga untuk meningkatkan daya simpan benih kacang panjang, karena perbedaan metode invigorasi menyebabkan perbedaan peningkatan kadar air (Chiu et al. 2002; Erinnovita et al. 2008).

Penelitian ini bertujuan untuk mendapatkan perlakuan benih diantara periode penyimpanan (middle storage treatment) untuk meningkatkan daya simpan benih kedelai (Glycine $\max ($ L.) Merr.)

\section{BAHAN DAN METODE}

Penelitian dilaksanakan pada bulan Desember 2013 hingga April 2014 di Laboratorium Ilmu dan Teknologi Benih, 
Departemen Agronomi dan Hortikultura Institut Pertanian Bogor, Darmaga Bogor. Bahan utama yang digunakan dalam penelitian ini adalah benih kedelai varietas baluran yang sudah disimpan selama 4 bulan pada ruang kamar dengan daya berkecambah awal $\pm 85 \%$. Bahan untuk perlakuan benih adalah air dan fungisida fungisida mankozeb. Plastik polipropilen (tebal $0.08 \mathrm{~mm}$ ) untuk wadah penyimpanan, dan kertas merang sebagai media pengecambah. Alat yang digunakan untuk penelitian ini adalah oven, alat pengepres kertas, alat pengecambah benih IPB 72-1, timbangan, gelas ukur dan kotak mika.

Penelitian dibagi menjadi dua percobaan. Percobaan pertama penyimpanan benih yang sudah diberi perlakuan dalam ruang suhu rendah $\left( \pm 5^{\circ} \mathrm{C}\right)$ dan percobaan kedua penyimpanan benih yang sudah diberi perlakuan dalam ruang kamar (26-30 $\left.{ }^{\circ} \mathrm{C}\right)$. Masing - masing percobaan dilakukan dengan rancangan petak tersarang (Nested Design) dengan dua faktor, yaitu faktor perlakuan benih dan periode simpan. Perlakuan benih meliputi (1) pencucian dengan air hangat $\left(50{ }^{\circ} \mathrm{C}\right)$ selama 3 menit, (2) pencucian dengan air dingin selama 3 menit, (3) pencucian dengan fungisida mankozeb konsentrasi $2 \mathrm{~g} \mathrm{~L}^{-1}$ selama 3 menit, (4) dan penjemuran dibawah matahari selama 6 jam. Benih yang telah diberi perlakuan (1), (2), dan (3) dikeringkan dengan cara dijemur di bawah matahari hingga mencapai kadar air 8 9\% . Benih kontrol dan benih yang telah diberi perlakuan kemudian dikemas menggunakan plastik polipropilen dan direkatkan dengan menggunakan sealer. Benih disimpan pada 2 ruang simpan, suhu dan RH kamar serta suhu dan RH pendingin (refrigerator). Pengujian viabilitas dilakukan setiap 2 minggu hingga 16 minggu penyimpanan. Pengujian viabilitas dilakukan di laboratorium menggunakan metode UKDdp (uji kertas digulung didirikan dalam plastik). Setiap perlakuan diulang tiga kali (ulangan tersarang pada periode simpan) dan setiap ulangan terdiri atas 25 butir benih. Pengujian kadar air benih juga dilakukan pada setiap akhir periode simpan dengan metode langsung oven suhu rendah $103 \pm 2{ }^{\circ} \mathrm{C}$ selama 17 \pm 1 jam dengan sampel $\pm 5 \mathrm{~g}$.

Data hasil percobaan dianalisis menggunakan sidik ragam menggunakan uji $\mathrm{F}$ pada taraf 5\%, kemudian dilakukan uji lanjut menggunakan Duncan Multiple Range Test (DMRT) untuk masing-masing tempat penyimpanan.

\section{HASIL DAN PEMBAHASAN}

Pengaruh Perlakuan Benih antar Periode Simpan terhadap Viabilitas Benih di Penyimpanan Suhu Rendah $\left( \pm 5^{\circ} \mathrm{C}\right)$.

Rekapitulasi hasil sidik ragam (Tabel 1) menunjukkan bahwa faktor perlakuan berpengaruh sangat nyata pada semua tolok ukur pengamatan. Faktor periode simpan berpengaruh sangat nyata terhadap tolok ukur daya berkecambah, indeks vigor, kecepatan tumbuh serta nyata pada tolok ukur kadar air.

Tabel 1. Rekapitulasi sidik ragam pengaruh perlakuan dan periode simpan terhadap tolok ukur DB, IV, $\mathrm{K}_{\mathrm{CT}}$ dan $\mathrm{KA}$ benih kedelai pada penyimpanan suhu rendah $\left( \pm 5^{\circ} \mathrm{C}\right)$

\begin{tabular}{lccc}
\hline Tolak Ukur & Perlakuan & Periode & $\begin{array}{l}\text { KK } \\
(\%)\end{array}$ \\
\hline $\begin{array}{l}\text { Daya } \\
\text { berkecambah } \\
\text { (DB) }\end{array}$ & $*$ & $*$ & 5.89 \\
\hline $\begin{array}{l}\text { Indeks vigor } \\
\text { (IV) }\end{array}$ & $*$ & $*$ & 12.48 \\
\hline $\begin{array}{l}\text { Kecepatan } \\
\text { tumbuh } \\
\left(\mathrm{K}_{\mathrm{CT}}\right)\end{array}$ & $*$ & $*$ & 6.53 \\
\hline $\begin{array}{l}\text { Kadar air } \\
\text { (KA) }\end{array}$ & $*$ & $*$ & 4.38 \\
$\begin{array}{l}\text { Keterangan :**= berpengaruh sangat nyata pada } \alpha=1 \% ; \\
\text { berpengaruh nyata } \alpha=5 \% ; \text { KK= Koefisien } \\
\text { kolerasi }\end{array}$
\end{tabular}

Tabel 2 menunjukkan pengaruh periode simpan selama 16 MSP terhadap tolak ukur pengamatan kadar air, daya berkecambah, indeks vigor serta kecepatan tumbuh benih kedelai yang telah diberi perlakuan. Kadar air pada penyimpanan refrigerator cenderung stabil, perubahan hanya terjadi pada 2 MSP untuk tercapai keseimbangan. Kadar air yang stabil dalam penyimpanan suhu rendah disebabkan kondisi suhu dan $\mathrm{RH}$ ruang simpan yang juga stabil dengan suhu $\pm 5{ }^{\circ} \mathrm{C}$ dan $\mathrm{RH}$ 60-70\%. Hasil penelitian Purwanti (2004) menunjukkan laju kenaikan kadar air benih kedelai pada suhu rendah berlangsung lebih lambat daripada suhu tinggi yaitu rata-rata $0.3 \%$ perbulannya. Oleh karena itu pada suhu rendah, aktivitas enzim terutama enzim respirasi dapat ditekan, sehingga perombakan cadangan makanan juga ditekan, proses deteriorasi dapat ditekan. Matinya sel-sel meristematis dan habisnya cadangan makanan dan 
degradasi enzim dapat diperlambat, sehingga viabilitas dan vigor masih tinggi.

Daya berkecambah mengalami penurunan dari $91.60 \%$ menjadi $84.67 \%$ benih kedelai pada selama penyimpanan 16 MSP dengan sedikit fluktuasi. Penyimpanan selama 16 MSP juga mengakibatkan penurunan vigor benih, indeks vigor turun dari $85.60 \%$ menjadi $41.20 \%$ dan kecepatan tumbuh juga mengalami penurunan dari $29.73 \%$ etmal $^{-1}$ menjadi $22.43 \%$ etmal $^{-1}$. Berdasarkan hasil ini maka dapat dikatakan bahwa waktu penelitian cukup untuk menunjukkan ada atau tidaknya pengaruh perlakuan benih dalam mempertahankan viabilitas benih selama penyimpanan.

Tabel 2. Pengaruh periode simpan terhadap tolak ukur DB, IV, KCT dan KA benih kedelai pada penyimpanan suhu rendah $\left( \pm 5^{\circ} \mathrm{C}\right)$

\begin{tabular}{lllll}
\hline \multirow{2}{*}{ Periode simpan } & \multicolumn{4}{c}{ Tolak ukur } \\
\cline { 2 - 5 } & DB $(\%)$ & IV $(\%)$ & $\mathrm{K}_{\mathrm{CT}}\left(\%\right.$ etmal $\left.^{-1}\right)$ & KA $(\%)$ \\
\hline $0 \mathrm{MSP}$ & $91.60 \mathrm{a}$ & $85.60 \mathrm{a}$ & $29.73 \mathrm{a}$ & $8.75 \mathrm{~b}$ \\
$2 \mathrm{MSP}$ & $88.40 \mathrm{abc}$ & 84.67 & $28.97 \mathrm{a}$ & $9.34 \mathrm{a}$ \\
$4 \mathrm{MSP}$ & $88.80 \mathrm{ab}$ & $73.60 \mathrm{~b}$ & $27.57 \mathrm{~b}$ & $9.22 \mathrm{a}$ \\
$6 \mathrm{MSP}$ & $90.00 \mathrm{a}$ & $66.40 \mathrm{c}$ & $26.85 \mathrm{~b}$ & $9.09 \mathrm{a}$ \\
$8 \mathrm{MSP}$ & $88.13 \mathrm{abc}$ & $43.60 \mathrm{de}$ & $23.44 \mathrm{c}$ & $9.19 \mathrm{a}$ \\
$10 \mathrm{MSP}$ & $85.73 \mathrm{bc}$ & $45.47 \mathrm{de}$ & $23.21 \mathrm{c}$ & $9.13 \mathrm{a}$ \\
$12 \mathrm{MSP}$ & $84.67 \mathrm{c}$ & $35.07 \mathrm{f}$ & $21.61 \mathrm{~d}$ & $9.29 \mathrm{a}$ \\
$14 \mathrm{MSP}$ & $85.20 \mathrm{bc}$ & $39.20 \mathrm{ef}$ & $22.27 \mathrm{dc}$ & $9.11 \mathrm{a}$ \\
$16 \mathrm{MSP}$ & $84.67 \mathrm{c}$ & $41.20 \mathrm{dc}$ & $22.43 \mathrm{dc}$ & $9.22 \mathrm{a}$ \\
\hline KK $(\%)$ & 5.89 & 12.48 & 6.53 & 4.38 \\
\hline
\end{tabular}

Keterangan: Angka yang diikuti dengan huruf yang sama pada baris dan kolom tidak berbeda nyata pada DMRT 5\%; KA= Kadar Air; IV = Indeks Vigor; DB= Daya Berkecambah; KCT= Kecepatan Tumbuh; Msp= minggu setelah perlakuan benih; KK= Koefisien kolerasi.

Pengaruh jenis perlakuan benih terhadap tolak ukur pengamatan dapat dilihat pada Tabel 3. Kadar air paling rendah dari semua perlakuan adalah perlakuan kontrol disusul perlakuan pencucian air dingin dan perlakuan jemur yang memiliki hasil tidak berbeda nyata. Kadar air paling tinggi adalah benih yang diberi perlakuan pencucian dengan fungisida mankozeb kemudian disusul benih yang diberi perlakuan pencucian dengan air panas. Hasil percobaan menunjukkan daya berkecambah benih yang diberi perlakuan pencucian fungisida mankozeb dan diberi perlakuan jemur memiliki nilai yang paling tinggi, selanjutnya disusul benih yang diberi perlakuan pencucian air panas dan benih yang diberi perlakuan pencucian air dingin. Benih yang tidak diberi perlakuan (kontrol) memiliki nilai daya berkecambah paling rendah. Perlakuan pencucian dengan fungisida mankozeb memiliki nilai paling tinggi pada tolak ukur pengamatan indeks vigor dan kecepatan tumbuh. Perlakuan kontrol memiliki nilai paling rendah pada tolak ukur pengamatan indeks vigor dan kecepatan tumbuh.

Tabel 3. Pengaruh jenis perlakuan benih terhadap tolok ukur DB, IV, KCT dan KA pada penyimpanan suhu rendah $\left( \pm 5^{\circ} \mathrm{C}\right)$

\begin{tabular}{lllll}
\hline \multirow{2}{*}{ Perlakuan benih } & \multicolumn{3}{c}{ Tolak ukur } \\
\cline { 2 - 5 } & DB $(\%)$ & IV $(\%)$ & $\mathrm{K}_{\mathrm{CT}}\left(\% \mathrm{etmal}^{-1}\right)$ & $\mathrm{KA}(\%)$ \\
\hline Kontrol & $78.52 \mathrm{c}$ & $46.59 \mathrm{c}$ & $21.92 \mathrm{c}$ & $8.07 \mathrm{~d}$ \\
Fungisida & & & & \\
mankozeb & $91.85 \mathrm{a}$ & $65.93 \mathrm{a}$ & $27.16 \mathrm{a}$ & $10.28 \mathrm{a}$ \\
Air panas & $87.11 \mathrm{~b}$ & $58.44 \mathrm{~b}$ & $25.22 \mathrm{~b}$ & $10.03 \mathrm{~b}$ \\
Air dingin & $88.44 \mathrm{~b}$ & $57.56 \mathrm{~b}$ & $25.36 \mathrm{~b}$ & $8.70 \mathrm{c}$ \\
Jemur & $91.41 \mathrm{a}$ & $57.48 \mathrm{ab}$ & $25.95 \mathrm{~b}$ & $8.67 \mathrm{c}$ \\
\hline KK $(\%)$ & 5.89 & 12.48 & 6.53 & 4.38 \\
\hline
\end{tabular}

Keterangan : Angka yang diikuti dengan huruf yang sama pada baris dan kolom tidak berbeda nyata pada DMRT 5\%; $\mathrm{KA}=$ Kadar Air; IV = Indeks Vigor; $\mathrm{DB}=$ Daya Berkecambah; $\mathrm{K}_{\mathrm{CT}}=$ Kecepatan Tumbuh; KK= Koefisien kolerasi. 
Pengaruh Perlakuan Benih antar Periode Simpan terhadap Viabilitas Benih di Penyimpanan Suhu $\operatorname{Kamar}\left(26-30^{\circ} \mathrm{C}\right)$

Ruang kamar memiliki suhu dan RH yang fluktuatif. Suhu berfluktuasi antara $26-30{ }^{\circ} \mathrm{C}$, sedangkan RH berfluktuasi antara $60-78 \%$ dikarenakan kondisi yang tidak terkontrol dan dipengaruhi oleh faktor lingkungan. Viabilitas benih kedelai yang disimpan selama 16 minggu di ruang suhu kamar disajikan pada Tabel 4. Hasil sidik ragam menunjukkan faktor perlakuan benih dan periode simpan berpengaruh sangat nyata pada semua tolok ukur pengamatan.

Tabel 4. Rekapitulasi sidik ragam pengaruh perlakuan dan periode simpan terhadap tolok ukur DB, IV, $\mathrm{K}_{\mathrm{CT}}$ dan KA pada kondisi simpan $\operatorname{kamar}\left(26-30{ }^{\circ} \mathrm{C}\right)$

\begin{tabular}{lccc}
\hline Tolok ukur & $\begin{array}{l}\text { Perlakuan } \\
\text { Benih }\end{array}$ & $\begin{array}{l}\text { Periode } \\
\text { Simpan }\end{array}$ & $\begin{array}{l}\text { KK } \\
(\%)\end{array}$ \\
\hline $\begin{array}{l}\text { Daya } \\
\text { berkecambah } \\
\text { (DB) }\end{array}$ & $* *$ & $* *$ & 5.89 \\
$\begin{array}{l}\text { Indeks Vigor } \\
(\mathrm{IV})\end{array}$ & $* *$ & $* *$ & 12.48 \\
$\begin{array}{l}\text { Kecepatan } \\
\text { Tumbuh } \\
\text { (KCT) }\end{array}$ & $* *$ & $* *$ & 6.53 \\
$\begin{array}{l}\text { Kadar air } \\
\text { (KA) }\end{array}$ & $* *$ & $* *$ & 4.38 \\
\hline
\end{tabular}

Keterangan : $* *=$ berpengaruh sangat nyata pada $\alpha=1 \% ; \mathrm{KK}=$ Koefisien kolerasi.

Kondisi ruang suhu kamar yang tidak terkontrol dapat dipengaruhi oleh pengaruh lingkungan antara lain iklim dan cuaca, intensitas cahaya, ventilasi udara dan aktivitas manusia di dalam ruangan yang mempengaruhi kondisi udara ruang penyimpanan (Justice dan Bass 2002). Benih yang disimpan selama 16 minggu pada suhu ruang kamar kadar airnya cenderung terfluktuasi antara $8.76 \%-10.43 \%$ (Tabel 5), meskipun benih disimpan dalam kemasan polipropilen kadar air masih terfluktuasi. Hal ini karena perubahan $\mathrm{RH}$ yang sering kali terjadi pada kondisi alami, sesuai dengan pernyataan Asni (2010) bahwa kadar air benih akan meningkat atau menurun seiring dengan meningkat atau menurunnya kelembapan relatif. Perubahan ini akan terus berlangsung sampai tercapai keseimbangan. Menurut Justice dan Bass (2002), adanya fluktuasi kadar air disebabkan oleh sifat benih yang higroskopis sehingga akan selalu mengadakan keseimbangan dengan udara di sekitarnya.

Daya berkecambah, indeks vigor dan kecepatan tumbuh mengalami peningkatan pada awal penyimpanan lalu berangsur mengalami penurunan meskipun sempat terjadi fluktuasi. Perlakuan invigorasi pada kondisi simpan kamar mampu mempertahankan daya berkecambah benih selama 6 MSP. Indeks vigor dan kecepatan tumbuh hanya mampu dipertahankan selama 2 MSP baik pada kondisi simpan suhu rendah maupun suhu kamar. Vigor benih merupakan kemampuan benih untuk tumbuh normal pada keadaan lingkungan yang sub optimum. Menurut Sadjad (1993) keadaan sub optimum yang tidak menguntungkan di lapangan dapat menambah segi kelemahan benih dan mengakibatkan turunnya persentase perkecambahan serta lemahnya pertumbuhna selanjutnya.

Tabel 5. Pengaruh periode simpan terhadap tolak ukur DB, IV, KCT dan KA pada kondisi simpan kamar $\left(26-30{ }^{\circ} \mathrm{C}\right)$

\begin{tabular}{|c|c|c|c|c|}
\hline \multirow{2}{*}{ Periode simpan } & \multicolumn{4}{|c|}{ Tolak ukur } \\
\hline & $\mathrm{DB}(\%)$ & IV (\%) & $\mathrm{K}_{\mathrm{CT}}\left(\%\right.$ etmal $\left.^{-1}\right)$ & $\mathrm{KA}(\%)$ \\
\hline $0 \mathrm{MSP}$ & $90.13 \mathrm{ab}$ & $84.00 \mathrm{a}$ & $29.23 \mathrm{a}$ & $8.76 f$ \\
\hline $2 \mathrm{MSP}$ & $91.07 \mathrm{a}$ & $88.27 \mathrm{a}$ & $29.98 \mathrm{a}$ & $9.34 \mathrm{e}$ \\
\hline 4 MSP & $86.00 \mathrm{~cd}$ & $71.87 \mathrm{~b}$ & $26.78 b$ & $9.41 \mathrm{de}$ \\
\hline $6 \mathrm{MSP}$ & $88.53 \mathrm{abc}$ & $59.73 c$ & $25.67 b$ & $9.75 c$ \\
\hline $8 \mathrm{MSP}$ & $86.53 b c$ & $35.73 \mathrm{ef}$ & $22.07 \mathrm{~d}$ & $10.12 b$ \\
\hline $10 \mathrm{MSP}$ & $84.93 \mathrm{cde}$ & $49.07 \mathrm{~d}$ & $23.53 c$ & $9.79 b$ \\
\hline $12 \mathrm{MSP}$ & $81.73 \mathrm{e}$ & $37.60 \mathrm{e}$ & 21.36de & $10.43 b c$ \\
\hline $14 \mathrm{MSP}$ & $78.00 \mathrm{f}$ & $32.67 \mathrm{ef}$ & $19.96 \mathrm{f}$ & $9.99 b c$ \\
\hline $16 \mathrm{MSP}$ & $82.40 \mathrm{~cd}$ & $30.80 \mathrm{f}$ & $20.59 \mathrm{ef}$ & 9.68 \\
\hline $\mathrm{KK}(\%)$ & 5.89 & 12.48 & 6.53 & 4.38 \\
\hline
\end{tabular}


Pengaruh jenis perlakuan benih terhadap tolok ukur pengamatan viabilitas benih setelah disimpan pada kondisi simpan suhu kamar menunjukkan hasil yang sama dengan kondisi simpan suhu rendah. Benih yang diberi perlakuan pencucian fungisida dengan bahan aktif mankozeb, air panas, air dingin, dan benih yang diberi perlakuan dijemur memiliki nilai daya berkecambah, indeks vigor dan kecepatan tumbuh yang lebih tinggi dibanding kontrol (Tabel 6).

Tabel 6. Pengaruh jenis perlakuan terhadap tolak ukur DB, IV, KCT dan KA pada kondisi simpan kamar $\left(26-30{ }^{\circ} \mathrm{C}\right)$

\begin{tabular}{lllcc}
\hline \multirow{2}{*}{ Perlakuan benih } & \multicolumn{3}{c}{ Tolak ukur } \\
\cline { 2 - 5 } & DB (\%) & IV (\%) & $\mathrm{K}_{\mathrm{CT}}\left(\% \mathrm{etmal}^{-1}\right)$ & KA (\%) \\
\hline Kontrol & $77.11 \mathrm{c}$ & $45.70 \mathrm{c}$ & $21.52 \mathrm{c}$ & $8.91 \mathrm{c}$ \\
Fungisida & & & & \\
mankozeb & $89.85 \mathrm{a}$ & $59.63 \mathrm{a}$ & $25.92 \mathrm{a}$ & $10.63 \mathrm{a}$ \\
Air panas & $85.56 \mathrm{~b}$ & $55.85 \mathrm{ab}$ & $24.56 \mathrm{~b}$ & $10.44 \mathrm{a}$ \\
Air dingin & $87.33 \mathrm{ab}$ & $56.67 \mathrm{ab}$ & $25.02 \mathrm{~b}$ & $9.27 \mathrm{~b}$ \\
Jemur & $87.56 \mathrm{ab}$ & $54.22 \mathrm{~b}$ & $24.74 \mathrm{~b}$ & $9.23 \mathrm{~b}$ \\
\hline KK $(\%)$ & 5.89 & 12.48 & 6.53 & 4.38 \\
\hline
\end{tabular}

Keterangan : Angka yang diikuti dengan huruf yang sama pada baris dan kolom tidak berbeda nyata pada DMRT 5\%; KA= Kadar Air; IV = Indeks Vigor; DB= Daya Berkecambah; $\mathrm{K}_{\mathrm{CT}}=$ Kecepatan Tumbuh; KK= Koefisien kolerasi.

Secara umum dapat dilihat bahwa daya kecambah terbaik adalah pada perlakuan pencucian dengan fungisida dengan bahan aktif mankozeb, pencucian dengan air dingin dan perlakuan jemur (Tabel 7). Perlakuan pencucian dengan fungisida dengan bahan aktif mankozeb, pencucian dengan air dingin dan perlakuan jemur dapat mempertahankan daya berkecambah $(\mathrm{DB})>80 \%$ hingga 16 MSP baik pada penyimpanan suhu rendah maupun suhu tinggi. Perlakuan kontrol hanya mampu mempertahankan daya berkecambah $>80 \%$ sampai 6 MSP. Benih yang sudah disimpan lama kemungkinan mengalami kemunduran, selain itu apabila disimpan pada kondisi ruang simpan dengan kelembaban tinggi akan mudah terserang cendawan dan bakteri. Menurut Justice dan Bass (2002) pada kondisi yang lembab peningkatan panas hasil respirasi dapat menimbulkan banyak kerusakan pada benih yang disimpan.

Tabel 7. Daya berkecambah (\%) benih yang disimpan selama 16 minggu pada kondisi simpan suhu rendah $\left( \pm 5^{\circ} \mathrm{C}\right)$ dan kamar $\left(26-30{ }^{\circ} \mathrm{C}\right)$

\begin{tabular}{lllllllllll}
\hline \multirow{2}{*}{ Ruang } & Perlakuan & \multicolumn{8}{c}{ Periode (MSP) } \\
\cline { 2 - 10 } & benih & 0 & 2 & 4 & 6 & 8 & 10 & 12 & 14 & 16 \\
\hline \multirow{6}{*}{ R1 } & Kontrol & 82.67 & 82.00 & 81.33 & 84.67 & 76.00 & 78.00 & 78.00 & 74.00 & 70.00 \\
& Fungisida & 94.67 & 91.33 & 94.00 & 92.00 & 94.00 & 89.33 & 87.33 & 94.00 & 90.00 \\
& Mankozeb & & & & & & & & & \\
& Air panas & 92.67 & 84.00 & 92.00 & 88.00 & 88.67 & 84.00 & 85.33 & 84.67 & 84.67 \\
& Air dingin & 94.00 & 90.00 & 88.00 & 89.33 & 86.00 & 90.00 & 84.00 & 85.33 & 89.33 \\
& Jemur & 94.00 & 94.67 & 88.67 & 96.00 & 96.00 & 87.33 & 88.67 & 88.00 & 89.33 \\
\hline \multirow{6}{*}{ R1 } & Kontrol & 82.67 & 83.33 & 74.00 & 80.67 & 71.33 & 79.33 & 78.67 & 68.67 & 75.33 \\
& Fungisida & 96.67 & 94.67 & 90.00 & 95.33 & 90.67 & 87.33 & 89.33 & 80.67 & 84.00 \\
& Mankozeb & & & & & & & & & \\
& Air panas & 89.33 & 92.00 & 90.00 & 90.00 & 90.00 & 86.67 & 80.33 & 75.33 & 76.67 \\
& Air dingin & 92.67 & 94.00 & 89.33 & 88.00 & 89.33 & 82.00 & 78.67 & 84.00 & 88.00 \\
& Jemur & 89.33 & 91.33 & 86.67 & 88.67 & 91.33 & 89.33 & 82.00 & 81.33 & 88.00 \\
\hline
\end{tabular}

$\mathrm{R} 1=$ ruang simpan refrig erator; R2= ruang simpan kamar; Msp= minggu setelah perlakuan benih

Fungisida dengan bahan aktif mankozeb merupakan bahan aktif fungisida berbentuk tepung yang biasa digunakan untuk mengendalikan penyakit yang berasal dari jamur (fungal borne disease) berspektrum luas pada pertanian, hortikultura, florikultur, dan tanaman pangan. Perlakuan pencucian dengan fungisida dengan bahan aktif mankozeb terbukti memberikan hasil positif terhadap viabilitas benih. Benih yang diberi perlakuan fungisida 
dengan bahan aktif mankozeb mampu mempertahankan DB 90\% hingga akhir periode simpan (16 MSP) pada kondisi ruang simpan suhu rendah. Hasil penelitian Mariam (2006) menunjukkan bahwa perendaman benih cabai dengan fungisida dengan bahan aktif mankozeb memiliki daya berkecambah lebih tinggi daripada kontrol. Perlakuan matriconditioning + fungisida dengan bahan aktif mankozeb efektif menurunkan tingkat infeksi penyakit hingga 100\%. Sesuai dengan hasil penelitian Suryani (2003), fungisida dengan bahan aktif mankozeb dalam perlakuan matriconditioning dapat menurunkan tingkat kontaminasi Colletotrichum capsici pada benih cabai. Paulsrud et al. (2001) menyatakan bahwa perlakuan benih dengan fungisida sintetik memiliki manfaat penting, akan tetapi juga menimbulkan resiko tertentu. Salah satu resiko adalah paparan disengaja pekerja saat memproduksi atau menerapkan perawatan benih. Resiko kedua adalah kontaminasi lingkungan melalui penanganan yang tidak tepat pada perlakuan benih atau bahan kimia yang terkandung pada fungisida sintetik itu sendiri. Resiko yang paling berat dapat terjadi jika benih yang diberi perlakuan fungisida salah dikonsumsi. Hal ini menjadi sangat berbahaya pada benih kedelai, sehingga diharapkan ada perlakuan lain yang memberikan hasil yang sama atau lebih baik.

Perlakuan pencucian air dingin menunjukkan hasil DB lebih tinggi dibandingkan kontrol dan mampu mempertahankan DB 89.33\% hingga 16 MSP pada kondisi ruang simpan suhu rendah. Perlakuan ini dapat membersihkan benih dari cendawan dan bakteri. Sedikit peningkatan kadar air dilanjutkan dengan pengeringan kembali diharapkan dapat memberi manfaat invigorasi tanpa adanya resiko sebagaimana perlakuan soaking pada benih yang akan disimpan kembali. Hasil penelitian Utami (2013) melaporkan kelemahan metode soaking terletak pada kesulitan untuk menurunkan kadar air benih kembali. Benih hanya dapat dikeringkan hingga kadar air 12$13 \%$ dan bila dikeringkan lebih lanjut akan mengalami keretakan pada kulit benih. Kadar air yang relatif tinggi di ruang penyimpanan dikhawatirkan menjadi pintu terjadinya serangan cendawan jika benih akan disimpan kembali dalam jangka waktu yang lama pada kondisi simpan ruang kamar. Hasil penelitian Yullianida dan Murniati (2005) terhadap bunga matahari menunjukkan bahwa perlakuan soaking dengan air maupun larutan antioksidan hanya efektif pada periode simpan 0 bulan. Pencucian dengan air panas $\left(50{ }^{\circ} \mathrm{C}\right)$ diharapkan memberi pengaruh lebih baik dibanding air dingin karena dianggap mampu membersihkan benih dengan lebih baik dari kotoran dan mikroba. Pada kenyataan hasil penelitian perlakuan pencucian dengan air panas $\left(50{ }^{\circ} \mathrm{C}\right)$ menunjukkan hasil yang serupa dengan perlakuan pencucian air dingin bahkan berdasarkan nilai DB pada benih yang disimpan di suhu kamar setelah perlakuan menunujukkan kecenderungan perlakuan air dingin lebih baik dibanding air panas.

Perlakuan jemur menunjukkan hasil yang tidak berbeda nyata dengan perlakuan pencucian dengan fungisida dengan bahan aktif mankozeb dan pencucian dengan air dingin. Perlakuan jemur sama efektifnya dengan perlakuan pencucian air dingin karena mudah dilakukan selain itu tidak membutuhkan biaya yang mahal. Tujuan penjemuran adalah untuk membunuh cendawan dan bakteri pada benih. Menurut Agrios (2005) dan Mari et al. (2009), perlakuan fisik terhadap komoditas pertanian sebagai perlakuan pra dan pasca panen menggunakan panas dan iradiasi sinar UV merupakan perlakuan yang direkomendasikan karena murah, mudah, dapat mematikan patogen yang ada di permukaan komoditas, serta ramah lingkungan. Hasil percobaan Suherman dan Suwandi (2011) perlakuan UV-C dengan kontak langsung selama 5 menit dengan dosis $2 \mathrm{~J} / \mathrm{cm} 2$ menunjukkan bahwa konidia Colletotrichum gloeosporioides efektif tidak tumbuh. Siddiqui et al. (2011) melaporkan bahwa iradiasi dengan ultra violet (UV-C) pada benih kacang hijau dan kacang tanah selama $0,5,10,15,20,30$ dan 60 menit terbukti dapat mengurangi infeksi pada akar yang disebabkan oleh cendawan Macrophomina phaseolina, Rhizoctonia solani dan Fusarium spp. Hasil penelitian Cristin et al. (2013) menunjukkan perlakuan iradiasi UV-C selama 12 jam pada jarak $15 \mathrm{~cm}$ mampu menghambat pertumbuhan koloni cendawan model Microcyclus ulei. Menurut EAAE (2000) spektrum sinar matahari terdiri dari sinar tampak dan tidak tampak. Sinar tampak meliputi: merah, oranye, kuning, hijau dan ungu (diketahui sebagai warna pelangi). Sinar-sinar tidak tampak antara lain adalah Sinar Ultraviolet, Sinar-X, Sinar Gamma, Sinar Kosmik, Mikrowave, Gelombang listrik dan Sinar Inframerah.

Diantara perlakuan yang mampu mempertahankan viabilitas benih dengan baik, perlakuan fungisida dengan bahan aktif mankozeb adalah perlakuan yang paling beresiko karena fungisida dengan bahan aktif mankozeb termasuk fungisida sintetik. Penggunaan fungisida sintetik yang berlebihan dapat menyebabkan gangguan pada kesehatan manusia, 
polusi lingkungan dan berkembangnya jamur patogen yang resisten terhadap fungisida (Prapagdee et al. 2008). Perlakuan pencucian dengan air dingin diikuti dengan penjemuran dan perlakuan penjemuran tanpa pencucian memberikan hasil yang tidak berbeda (sama baiknya), sehingga perlakuan penjemuran menjadi perlakuan yang disarankan untuk mempertahankan viabilitas benih kedelai sebagai perlakuan antar periode simpan karena perlakuan ini paling mudah dan relatif tanpa resiko.

\section{KESIMPULAN}

Benih kedelai mengalami kemunduran selama penyimpanan. Perlakuan benih dengan pencucian dengan fungisida dengan bahan aktif mankozeb, pencucian dengan air dingin, dan penjemuran benih di bawah sinar matahari dapat meningkatkan viabilitas benih kedelai serta dapat mempertahankan daya berkecambah > $80 \%$ hingga akhir penyimpanan (16 MSP) baik pada penyimpanan suhu rendah $\left( \pm 5^{\circ} \mathrm{C}\right)$ maupun kamar $\left(26-30{ }^{\circ} \mathrm{C}\right)$, sementara pada kontrol hanya bertahan hingga 6 MSP.

\section{DAFTAR PUSTAKA}

Agrios, G, N. 2005. Plant Pathology . Elsevier Aca, Amsterdam.

Asni, N. 2010. Kadar air yang aman untuk penyimpanan benih tanaman pangan (jagung, kedelai, dan kacang tanah) [Internet]. [diunduh 2014 Juni 10]. Tersedia pada : http://www.digilib.litbang.deptan.go.id/ j ambi/getiptan.php?src=makalah/kaman.pd $\mathrm{f} \&$ format=application/pdf

Basra, S, M, A., Farooq, M., Wahid, A., Khan, M, B. 2006. Rice seed invigoration by hormonal and vitamin priming. Seed Sci and Technolog. 34:753-758.

Chiu, K, Y., Chen, C, L.,Sung, J, M. 2002. Effect of priming temperature on storability of primed sh-2 sweet corn seed. Crop Sci. 42:1996-2003.

Cristin, A., Sinaga, M, S., Adnan, A, M. 2013. Keefektifan perlakuan panas kering dan iradiasi UV-C untuk mematikan cendawan model Microcylus ulei. $J$ Fitopatol Ind. 9(2):59-67.
[EAAE] The European Association for Astronomy Education. 2000. Sunlight spectra [Internet]. (diunduh 2014 Agustus 28]. Tersedia pada :[http://eaaeastronomy.org/WG3SS/WorkShops/SunS pect.html

Erinnovita, Sari, M., Guntoro, D. 2008. Invigorasi benih untuk memperbaiki perkecambahan kacang panjang (Vigna sinensis (L.) Savi ex Hask ) pada cekaman salinitas. Bul Agron. 36(3):213-219.

Ilyas, S. 2001. Mutu Benih, Makalah dalam Studium Generale Fakultas Pertanian Universitas Tanjungpura. Fakultas Pertanian Institut Pertanian Bogor, Bogor.

Ilyas, S. 2006. Review: Seed treatments using matriconditioning to improve vegetable seed quality. Bul Agron. 34(2):124 - 132.

Justice, O, L., Bass, L, N. 2002. Prinsip dan Praktek Penyimpanan Benih. Roesli R, penerjemah.. Terjamahan dari: Principles and Practic of Seed Storage, Jakarta (ID) : PT Raja Grafindo Persada

Mari, M., Neri, F., Bertolini, P. 2009. New approach for postharvest diseases control in europe. Plant Pathology. 2:119-130.

Mariam. 2006. Pengaruh perlakuan matricondioning plus fungisida nabati terhadap pertumbuhan dan hasil cabai merah (Capsicum annuum L.). Skripsi. Institut Pertanian Bogor, Bogor.

Moosavi, S, S., Alaei, Y., Khanghah, A, M. 2014. The effect of water seed pre-treatment on soybean vegetatif and reproductive traits. IJA. 4(3A): 12-17.

Paulsrud, B, E., Martin, D., Babadoost, M., Malvick, D., Weinzierl, R., Lindholm, D, C., Steffey, K., Pederson, W., Reed, M., Maynard, R. 2001. Oregon Pesticide Applicator Training Manual, Seed Treatment. University of Illinois Broad of Trustees, Urbana.

Prapagdee, B., Akrapikulchart, U., Mongkolsuk, S. 2008. Potential of a soil-borne Streptomyces hygroscopicus for biocontrol of anthracnose disease caused 
by 14 Colletotrichum gloeosporioides in Orchid. J Bio Sci. 8(7):1187-1192.

Purwanti, S. 2004. Kajian suhu ruang simpan terhadap kualitas benih kedelai hitam dan kedelai kuning. Ilmu Pertanian. 11(1):2231.

[Puslitbangtan] Pusat Penelitian dan Pengembangan Tanaman Pangan. 2013. Invigorasi, alternatif atasi penurunan mutu benih kedelai. [Internet]. (diunduh 2013 November 21). Tersedia pada:http://www.litbangdeptan.go.id

Ruliansyah, A. 2011. Peningkatan performa benih kacangan dengan perlakuan invigorasi. J Tek Perkebunan \& PSDL. 1:13-18.

Sadjad, S. 1993. Dari Benih Kepada Benih. Jakarta (ID) : Gramedia

Siddiqui, A., Dawar, S., Zaki, M, J., Hamid, N. 2011. Role of ultra violet (UV-C) radiation in the control of root infecting fungi on groundnut and mung bean. Pak $J$ Bot. 43(4): 2221-2224.
Suherman, B., Suwandi, T. 2011. Perlakuan iradiasi sinar UV-C terhadap kedelai untuk mengeradikasi cendawan model Microcyclus ulei [Internet]. [diunduh 2014 Juni 11]. Tersedia pada: http://data.buttmkp.org/news/image/storie s/docs/uv-c.pdf

Suryani, N. 2003. Pengaruh perlakuan matriconditioning plus fungisida pada benih cabai merah (Capsicum annuum L.) dengan berbagai tingkat kontaminasi Colletotrichum capsici (Syd). Bult. Et Bisby. terhadap viabilitas dan vigor benih. [skripsi]. Institut Pertanian Bogor, Bogor.

Utami, E, P. 2013. Perlakuan priming benih untuk mempertahankan vigor benih kacang panjang (Vigna unguiculata) selama penyimpanan. Bul Agrohorti. 1(4):75-82.

Yullianida, Murniati, E. 2005. Pengaruh antioksidan sebagai perlakuan priming benih sebelum simpan terhadap daya simpan benih bunga matahari (Helianthus annuus L.) Hayati 12(4):145-150. 